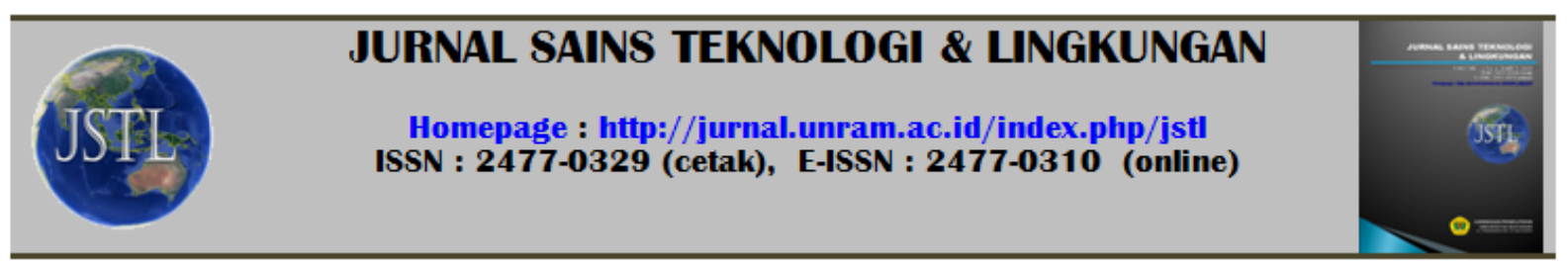

\title{
DETEKSI BAKTERI PATOGEN YANG BERASOSIASI DENGAN Kappaphycus alvarezii (Doty) BERGEJALA PENYAKIT ICE-ICE
}

\begin{tabular}{|c|c|}
\hline & $\begin{array}{l}\text { 1)Sri Nurhidayati, }{ }^{\mathbf{1}} \text { ) Faturrahman, }{ }^{\mathbf{1}} \text { ) Mursal Ghazali } \\
\left.{ }^{1}\right) \text { Program Studi Biologi Fakultas MIPA Universitas Mataram }\end{array}$ \\
\hline Kata kunci: & Abstrak \\
\hline $\begin{array}{l}\text { Kappaphycus } \\
\text { alvarezii, } \\
\text { penyakit ice-ice, } \\
\text { postulat Koch }\end{array}$ & $\begin{array}{l}\text { Kappaphycus alvarezii merupakan salah satu spesies makro alga yang paling banyak } \\
\text { dibudidayakan di Indonesia. Penyakit utama yang menyerang budidaya rumput laut ini } \\
\text { adalah penyakit ice-ice yang dapat menurunkan hasil panen hingga } 70-80 \% \text {. Tujuan } \\
\text { penelitian iniadalah untuk mengetahui bakteri patogen yang berasosiasi dengan } K \text {. } \\
\text { alvarezii bergejala penyakit ice-ice dan mengetahui agen penyebab penyakit ice-ice. } \\
\text { Jenis penelitian yang dilakukan adalah penelitian deskriptif. Sampel K. alvarezii yang } \\
\text { bergejala ice-ice diambil dari lokasi budidaya di Teluk Bumbang Dusun Gerupuk } \\
\text { Lombok Tengah. Sampel tersebut kemudian dibawa ke Laboratorium Biologi untuk } \\
\text { diisolasi bakteri yang berasosiasi dengan } K \text {. alvarezii bergejala ice-ice. Terhadap isolat } \\
\text { yang diperoleh dilakukan karakterisasi parsial. Selanjutnya dilakukan uji patogenisitas } \\
\text { (postulat Koch) untuk mengetahui apakah bakteri yang diperoleh merupakan agen } \\
\text { penyebab penyakit ice-ice. Hasil isolasi menunjukkan terdapat } 28 \text { isolat bakteri yang } \\
\text { berasosiasi dengan } K \text {. alvarezii bergejala ice-ice. Selanjutnya, uji postulat Koch } \\
\text { memperlihatkan hanya satu isolat yang mampu menyebabkan gejala ice-ice yaitu isolat } \\
\text { K25. }\end{array}$ \\
\hline
\end{tabular}

\begin{tabular}{ll}
\hline Key words : & Abstract \\
\hline Kappaphycus & Kappaphycus alvarezii is one of macro-algae species most widely cultivated in \\
alvarezii, ice-ice, & Indonesia. The main diseases that attack the cultivation of seaweed are ice-ice disease \\
Koch's postulates & that can reduce yields by 70-80\%. The purpose of this study is to determine the \\
bacterial pathogens associated with ice-ice symptomatic K.Alvarezii and determine the \\
causative agent of ice-ice disease. Samples ice-icesymptomaticK.alvarezii taken from \\
farms in the Gulf Bumbang Gerupuk Dusun Central Lombok. The sample is then taken \\
to the Laboratory of Biology for isolated bacteria associated with symptomatic \\
K.alvarezii ice-ice. then performed a partial characterization of the bacterial isolates \\
were obtained. Furthermore, the pathogenicity test (Koch's postulates) to determine \\
whether the bacteria were obtained by a disease-causing agents ice-ice. The results \\
showed there were 28 isolates isolation of bacteria associated with symptomatic \\
alvarezii K. ice-ice. Furthermore, Koch's postulates test showed only one isolate \\
capable of causing symptoms ice-ice that isolates K25.
\end{tabular}




\section{PENDAHULUAN}

Kappaphycus alvarezii merupakan salah satu spesies makro alga yang memiliki banyak manfaat. Banyak industri menggunakan $K$. alvarezii sebagai salah satu bahan utama dan pelengkap dalam produk seperti: industri farmasi, kosmetik, makanan, dan lain-lain (Kadi, 2004). Seiring dengan meningkatnya pemanfaatan makro alga, maka permintaan pasar baik di dalam maupun di luar negeri juga semakin tinggi. Permintaan pasar yang tinggi, bibit yang mudah diperoleh, dan harga jual yang tinggi menyebabkan jenis $K$. alvarezii paling banyak dibudidayakan di wilayah perairan Indonesia (Santoso \& Nugraha, 2007). Namun, terdapat kendala yang dihadapi oleh pembudidaya makro alga, yaitu menurunnya hasil panen yang disebabkan oleh serangan penyakit.

Penyakit utama yang menyebabbkan penurunan produksi di seluruh pusat pengembangan budidaya makro alga adalah penyakit ice-ice (Aris, et al., 2013).Serangan penyakit tersebut tidak hanya menurunkan hasil panen (60-70\%), tetapi dapat juga menyebabkan gagal panen (Hamsah \& Patadjai, 2013), seperti di Pulau Pari, Kepulauan Seribu, Jakarta para nelayan yang membudidayakan $K$. alvarezii hampir tidak mendapatkan hasil panen dari tahun 2000 sampai 2004 karena terserang penyakit ice-ice(Yulianto dan Mira, 2009). Serangan ice-ice di Nusa Penida menurunkan produksi dari 500 ton (tahun 2007) menjadi 200 ton (tahun 2008). Penurunan ini membuat volume ekspor makro alga Indonesia anjlok sebesar 97,8\% tahun 2007 (Widiastuti, 2009).

Melihat besarnya dampak dari serangan penyakit yang ditimbulkan maka perlu dilakukan usaha penanggulangan, salah satunya adalah dengan pemilihan bibit unggul. Akan tetapi perubahan lingkungan yang ekstrim dan serangan predator dapat melemahkan kondisi fisik dan menyebabkan stres pada makro alga. Keadaan tersebut memudahkan infeksi patogen, karena makro alga membebaskan substansi organik yang menyebabkan thallus berlendir, dan merangsang bakteri tumbuh melimpah (Jailani et al., 2011).

Berdasarkan hasil penelitian di beberapa tempat, telah teridentifikasi bakteri yang terdapat pada makro alga $K$. alvarezii yang bergejala ice-ice yaituVibrio cholerae (Hamsah \& Patadjai, 2012), Vibrio alginolyticus (Aris et al., 2013), Aeromonas sp., Proteus sp. (Darmayati et al., 2001), Pseudomonas spp., Pseudoalteromonas gracilis, Vibro spp. (Arisandi et al., 2011; Santoso dan Nugraha, 2007), Chrommobacterium, Acinotobacter (dominan), Flavocytofaga, Vibrio (Nurjanna, 2008 dalamArisandi et al., 2011).Oleh sebab itu, dalam upaya penanggulangan terhadap kemungkinan serangan penyakit ice-ice di Pulau Lombok, perlu dilakukan deteksi bakteri yang berasosiasi dengan $K$. Alvarezii bergejala ice-ice dan mengevaluasi bakteri patogen yang berasosiasi dengan $K$. alvareziibergejala penyakit ice-ice melalui penerapan postulat Koch

\section{METODOLOGI PENELITIAN}

\section{Isolasi Bakteri yang Berasosiasi Dengan $K$. alvarezii bergejala Penyakit Ice-ice}

Bakteri diisolasi dariK. alvarezii bergejala penyakit ice-ice yang diperoleh dari Teluk Bumbang Dusun Gerupuk, Desa Sengkol Kecamatan Pujut Lombok Tengah. Persiapan sampel dilakukan pertama-tama bagian dari tallus $K$. alvareziyang bergejala penyakit ice-ice dipotong dan dihaluskan dalam laminar air flowkemudian ditimbang sebanyak satu gram. Selanjutnya dilakukan pengenceran $10^{-1}, 10^{-2}$, $10^{-3}, 10^{-4}, 10^{-5}$, dan $10^{-6}$ menggunakan $\mathrm{NaCl}$ fisiologis. Sebanyak $0,1 \mathrm{~mL}$ diambil dari tiga seri pengenceran $\left(10-^{3}, 10^{-}, 10^{-5}\right)$ ditanam pada media marine agar (MA) dengan teknik agar sebar. Kemudian diinkubasi pada suhu $28^{\circ} \mathrm{C}$ selama 24 jam.

\section{Karakterisasi Parsial Bakteri yang Berasosiasi Dengan $K$. alvarezii bergejala Penyakit Ice-ice}

\section{a. Pengamatan Morfologi}

Pengamatan morfologi yang dilakukan meliputimorfologi sel dan morfologi koloni. Pengamatan morfologi selsecara mikroskopik dilakukan pada saat pewarnaan gram. Sedangkan, pengamatan morfologi koloni dilakukan setelah mendapatkan biakan murni. Pengamatan ini meliputi warna, permukaan koloni (halus, kasar), bentuk (form), tepian koloni (margin), dan elevasi.

\section{b. Pewarnaan Gram}

Pengamatan morfologi sel bakteri dilakukan dengan pewarnaan Gram. 1-2 tetes aquades steril diletakkan di atas kaca objek, koloni bakteri di ambil satu ose dari media diletakkan di atas aquades steril dan sebarkan 
hingga merata, biarkan olesan tersebut kering karena udara. Setelah olesan benar-benar kering kemuadian lalukan kaca objek tersebut beberapa kali di atas nyala api sampai kaca objek terasa agak panas bila ditempelkan pada punggung tangan. Kemudian ditetesi dengan larutan kristal ungu (Gram A), dan didiamkan selama satu menit, kemudian cuci menggunakan aquades pada botol semprot dan dikeringkan. Selanjutnya ditetesi dengan larutan iodium (Gram B) dan dibiarkan selama 2 menit, dicuci menggunakan aquades pada botol semprot dan dikeringkan. Kemudian ditetesi dengan larutan etanol 95\% (Gram C) selama 30 detik, dicuci menggunakan aquades pada botol semprot dan dikeringkan. Setelah itu ditetesi dengan larutan safranin (Gram D) atau zat penutup dan didiamkan selama 30 detik, kemudian dicuci menggunakan aquades pada botol semprot dan dikeringkan. Selanjutnya diamati dengan menggunakan mikroskop pada pembesaran kuat (Waluyo, 2010). Indikasi pewarnaannya yaitu bakteri gram positif akan berwarna violet dan bakteri gram negatif akan berwarna merah. Dicatatdan difoto bentuk dari sel bakteri tersebut apakah bulat (coccus), batang (basil), maupun bergelombang (spiral).

c. Reaksi Biokimia Isolat BakteriMedia TCBS (Thiosulphate Citrate Bile-Salts Sucrose) Agar

Bakteri ditumbuhkan pada media TCBS dilakukan dengan menggoreskan isolat bakteri (telah diisolasi sebelumnya) pada cawan Petri. Cawan diinkubasi pada inkubator pada suhu $28^{\circ} \mathrm{C}$ selama $24 \mathrm{jam}$. Diamati warna koloni dan perubahan warna yang terjadi pada media.

\section{Media MacConkey Agar}

Bakteri ditumbuhkan pada media MacConkey Agar (MCA) dengan metode gores. Diinkubasi pada suhu $28^{\circ} \mathrm{C}$ selama 24 jam. Diamati warna koloni yang tumbuh.

\section{Uji Katalase}

Uji katalase dilakukan dengan menempatkan satu ose koloni pada kaca obyek kemudian teteskan 1-2 hydrogen peroksida, amati terbentuknya gelembung untuk hasil positif dan tidak terbentuk gelembung untuk hasil negatif.

\section{Uji Glukosa}

Uji glukosa dilakukan dengan cara memindahkan sebanyak 1 ose dari tiap koloni ke media Glucose Broth (GB) dalam tabung reaksi dan diinkubasi pada suhu $28^{\circ} \mathrm{C}$ selama 24 jam.
Adanya pertumbuhan pada tabung reaksi GB menunjukkan bakteri dapat memfermentasikan glukosa yang ditandai dengan terbentuknya gelembung.

\section{Penerapan Postulat Koch (Uji \\ Patogenisitas)}

Uji patogenisitas digunakan untuk mengkonfirmasi apakah bakteripatogen yang berhasil diisolasi dari makro alga yangsakit mampu menginfeksi kembali makro alga yang sehat dengan gejala yang sama.

\section{Penyajian Data}

Data disajikan dalam bentuk gambar dan tabel, kemudian dianalisis menggunakan metode deskriptif, yaitu dengan mendeskripsikan atau menggambarkan data-data yang diperoleh selama proses penelitian secara jelas yang didukung dengan kajian pustaka

\section{HASIL DAN PEMBAHASAN}

\section{Isolat Bakteri yang Berasosiasi dengan Kappaphycus alvarezii Bergejala Ice-ice}

Hasil isolasi bakteri pada $K$. alvarezii bergejala ice-ice yang diambil dari budidaya makro alga di teluk Bumbang Lombok Tengah yaitu diperoleh 28 isolat bakteri. Isolat bakteri tersebut memiliki karakter morfologi yang berbeda-beda yang disajikan dalam tabel 1 . Namun, ke-28 isolat bakteri yang diperoleh belum bias dipastikan genus maupun spesiesnya, karena untuk bias memastikan keduanya harus melakukan lebih banyak uji-uji biokimia. Pada penelitian ini, hasil isolasi bakteri ditulis dalam bentuk kode, seperti K1,K2, K3, dan seterusnya sampai k28.

Arisandi \& Farid (2014) menyatakan bahwa, bakteri yang dapat diisolasi dari makro alga yang bergejala ice-ice adalah Pseudoalteromonas gracilis, Pseudomonas spp., dan vibrio spp. Darmayati (2010) telah melakukan uji patogenesitas 8 isolat terhadap K. alvarezii, menunjukkan bahwa 5 isolat dapat menimbulkan gejala ice-ice. Bakteri tersebut adalah Bacillus cereus, Vibrio granii, V. agarliquefaciens, Pseudomonas nigrifaciens, dan P.fluorescens. B. cereus memiliki daya patogenitas tertinggi.

\section{Karakterisasi Parsial Isolat Bakteri \\ Pengamatan morfologi Koloni}

Berdasarkan hasil pengamatan morfologi koloni pada media marine agar (MA) ke-28 koloni bakteri memiliki berbagai bentuk, warna, tepian (margin), elevasi, permukaan, dan 
ukuran. Bentuk koloni bulat memiliki jumlah yang dominan dengan warna yang beragam yaitu kuning, putih, abu, bening, dan krem. Koloni dengan tepian entire lebih dominan dibandingkan tepian koloni undulate, lobate, dan curled dengan permukaan koloni ada yang halus dan ada yang kasar. Untuk lebih lengkapnya hasil tersebut disajikan dalam bentuk tabel 1 sebagai berikut.

Tabel 1Jumlah dan Morfologi Koloni Isolat Bakteri yang berasosiasi dengan $K$. alvarezii bergejala ice-ice.

\begin{tabular}{|c|c|c|c|c|c|c|c|}
\hline \multirow[t]{2}{*}{$\mathrm{N}_{0}$} & \multirow{2}{*}{$\begin{array}{l}\text { Koloni } \\
\text { Bakteri }\end{array}$} & \multicolumn{6}{|c|}{ Morfologi Koloni Bakteri } \\
\hline & & Bentuk & Warna & Tepian & Elevansi & Permukaan & Ukuran \\
\hline 1 & $\mathrm{~K} 1$ & Bulat & Kuning & Entire & Convex & Halus & Kecll \\
\hline 2 & $\mathrm{~K} 2$ & Bulat & Kuning & Entire & Convex & Halus & Kecil \\
\hline 3 & $\mathrm{~K} 3$ & Bulat & Kuning & Entire & Raised & Kasar & Kecil \\
\hline 4 & $\mathrm{~K} 4$ & Bulat & Kuning & Entire & Convex & Halus & Kecil \\
\hline 5 & K5 & Bulat & Kuning & Entire & Convex & Halus & Sedang \\
\hline 6 & K6 & Bulat & Kuning & Entire & Convex & Halus & Sedang \\
\hline 7 & $\mathrm{~K} 7$ & Bulat & Putih & Entire & Convex & Halus & Sedang \\
\hline 8 & $\mathrm{~K} 8$ & Bulat & Putih & Entire & Umbonate & Halus & Sedang \\
\hline 9 & $\mathrm{~K} 9$ & Bulat & Putih & Entire & Convex & Halus & Sedang \\
\hline 10 & $\mathrm{~K} 10$ & Bulat & Puth & Entire & Convex & Halus & Sedang \\
\hline 11 & K11 & Bulat & Abu & Undulate & Umbonate & Kasarf & Kecil \\
\hline 12 & $\mathrm{~K} 12$ & Bulat & Putih & Undulate & Raised & Halus & Sedang \\
\hline 13 & $\mathrm{~K} 13$ & Bulat & Kuning & Entire & Convex & Halus & Kecil \\
\hline 14 & K14 & Bulat & Putih & Entire & Convex & Halus & Kecil \\
\hline 15 & $\mathrm{~K} 15$ & Bulat & $\begin{array}{l}\text { Puthih } \\
\text { bening }\end{array}$ & Entire & Flat & Halus & Sedang \\
\hline 16 & K16 & Bulat & Krem & Entire & Convex & Halus & Kecil \\
\hline 17 & $\mathrm{~K} 17$ & Bulat & Putih & Entire & Flat & Halus & Sedang \\
\hline 18 & K18 & Bulat & Krem & Entire & Convex & Halus & Kecil \\
\hline 19 & $\mathrm{~K} 19$ & Bulat & Krem & Undulate & Flat & Halus & Kecil \\
\hline 20 & $\mathrm{~K} 20$ & Bulat & Putih & Entire & Convex & Halus & Kecil \\
\hline 21 & $\mathrm{~K} 21$ & Ifregular & Bening & Lobate & Flat & Kasar & Kecil \\
\hline 22 & $\mathrm{~K} 22$ & Bulat & Krem & Entire & Flat & Halus & Sedang \\
\hline 23 & $\mathrm{~K} 23$ & Ifregular & Krem & Curled & Raised & Kasar & Kecil \\
\hline 24 & $\mathrm{~K} 24$ & Bulat & Krem & Entire & Flat & Halus & Kecil \\
\hline 25 & $\mathrm{~K} 25$ & Bulat & Krem & Entire & Convex & Halus & Sedang \\
\hline 26 & $\mathrm{~K} 26$ & Bulat & Putih & Undulate & Flat & Halus & Kecil \\
\hline 27 & $\mathrm{~K} 27$ & Bulat & Putih & Entire & Flat & Halus & Kecil \\
\hline 28 & $\mathrm{~K} 28$ & Bulat & Putih & Entire & Umbunate & Halus & Kecil \\
\hline
\end{tabular}

Dengan K. alvarezı Bergejala Penyakıt Ice-ıce Berdasarkan Uji Gram

Tabel 2 Komposisi Bakteri yang Berasosiasi Dengan K. alvarezii Bergejala Penyakit Ice-ice Berdasarkan Uji Gram

\begin{tabular}{ccccc}
\hline Bentuk & Jumlah & Persentasi $(\%)^{*}$ & \multicolumn{2}{c}{ Gram } \\
\cline { 3 - 5 } & $(\Sigma)$ & & Positif & Negatif \\
\hline Bacil & 20 & 71.43 & 18 & 2 \\
Coccus & 8 & 28.57 & 8 & 0 \\
\hline Total & 28 & 100 & 26 & 2 \\
\hline Keterangan*: persentasi terhadap total isolat & \multicolumn{3}{c}{}
\end{tabular}

Hasil Pengamatan pewarnaan Gram (Tabel 2) menunjukkan 26isolat bakteri bersifat Gram positif dandua isolat lainnya bersifat Gram negatif. Bakteri gram positif pada pewarnaan Gram berwarna ungu disebabkan kompleks zat warna kristal violet-yodium tetap dipertahankan meskipun diberi larutan alkohol, sedangkan bakteri gram negatif berwarna merah sebab kompleks tersebut larut pada saat pemberian larutan alkohol sehingga mengambil warna merah safranin. Perbedaan warna pada bakteri gram positif dan gram negatif menunjukkan bahwa adanya perbedaan struktur dinding sel antara kedua jenis bakteri tersebut. Bakteri gram positif memiliki struktur dinding sel dengan kandungan peptidoglikan yang tebal sedangkan bakteri Gram negatif memiliki struktur dinding sel dengan kandungan lipid yang tinggi (Lay, 1994).

Pewarnaan Gram selain untuk uji Gram positif dan Gram negatif pada bakteri, juga dilakukan untuk pengamatan morfologi sel bakteri. Berdasarkan hasil pengamatan morfologi sel dari 28 isolat diperoleh bakteri bentuk bacil 20 isolat (71.43\%) dan bentuk coccus 8 isolat (28.57\%) (Tabel 2). Kehadiran bakteri berbentuk bulat (coccus) pada K. alvarezii kemungkinan disebabkan karena bakteri ini tidak memiliki alat gerak sehingga untuk mempertahankan hidup dengan cara melekatkan diri pada suatu benda yang terdapat di perairan. Hal ini didukung oleh pernyataan Hutching dan Saenger (1987) dalam Jaelani (2014) menyatakan bahwa kebanyakan bakteri coccus terikat atau bergabung sesamanya untuk membentuk permukaan yang kuat (solid) karena adanya bahan berlendir sehingga sel-sel saling terikat. mengakibatkan bakteri dapat hidup pada alga, rumput laut, lamun, dan karang. Bakteri bentuk bacil dapat hidup di perairan karena memiliki flagel yang digunakan sebagai alat gerak. Sidharta, (2000) menyatakan flagellum memungkinkan bakteri bergerak menuju kondisi lingkungan yang menguntungkan atau menghindar dari lingkungan yang merugikan bagi kehidupannya.

\section{Reaksi Biokimia Isolat Bakteri}

Karakterisasi biokimia terhadap ke-28 isolat bakteri bertujuan untuk memudahkan menyamakan karakter ketika dilakukan karakterisasi ulang isolat bakteri yang mampu menyebabkan gejala ice-ice pada uji postulat Koch.

Tabel 3 Hasil Aktivitas Biokimia Isolat Bakteri yang Berasosiasi dengan $K$. alvarezii bergejala

\begin{tabular}{cccccc}
\hline No & Kode Koloni & \multicolumn{5}{c}{ Karaktenisasi } \\
\cline { 3 - 6 } & Bakten & $\begin{array}{c}\text { TCBS } \\
\text { Warna koloni }\end{array}$ & $\begin{array}{c}\text { MCA } \\
\text { Warna koloni }\end{array}$ & $\begin{array}{c}\text { Uji } \\
\text { Katalase }\end{array}$ & $\begin{array}{c}\text { Uji } \\
\text { Glukosa }\end{array}$ \\
\hline 1 & K1 & Kuning & - & + & - \\
2 & K2 & Kuning & - & + & - \\
3 & K3 & Kuning & - & + & - \\
4 & K4 & Kuning & - & + & - \\
5 & K5 & Kuning & Pink & + & - \\
6 & K6 & Kuning & - & + & + \\
7 & K7 & Puth & Pink & + & + \\
8 & K8 & Putih & Pink & + & - \\
9 & K9 & Puth & - & + & - \\
10 & K10 & Putih & - & + & + \\
11 & K11 & Hijau & - & + & - \\
12 & K12 & Kuning & Pink & + & - \\
13 & K13 & Kuning & - & + & + \\
14 & K14 & Kuning & Pink & + & + \\
15 & K15 & Kuning & Pink & + & - \\
16 & K16 & Kuning & Pink & + & + \\
\hline
\end{tabular}




\section{Penerapan Postulat Koch (Uji Patogenesitas)}

Terhadap ke-28 isolat yang diisolasi dari $K$. alvarezii bergejala ice-ice dilakukan uji postulat Koch untuk mendeterminasi isolat mana yang bersifat patogen. Pada kegiatan ini, telah dilakukan uji tahap ketiga dan keempat dari postulat Koch yaitu biakan murni tersebut bila diinjeksikan pada organisme yang sesuai dapat menimbulkan penyakit dan mikroorganisme tersebut dapat diisolasi kembali dari organisme yang telah terinfeksi tersebut.

Hasil uji patogenesitas (postulat Koch) dari 28 isolat bakteri terdapat satu koloni yang mampu menyebabbakn $K$. alvarezii bergejala ice-ice yaitu K25. Dikatakan mampu menyebabkan gejala ice-ice karena isolat ini telah menginfeksi $K$. alvarezii pada kedua ulangan sampel uji, sedangkan isolat lainnya hanya menyebabkan infeksi pada satu sampel uji atau bahkan ada isolat yang tidak menyebkan infeksi pada kedua sampel uji. Sampel uji yang telah diinokulasikan isolat K25 pada pengamatan hari ke-1 sudah mulai terjadi sedikit pemutihan pada pangkal thallus, pada pengamatan hari ke-2 dan ke-3 area pemucatan thallus semakin meluas, pada pengamatan ke-4 atau pengamatan terakhir pemucatan hampir melingkupi seluruh permukaan thallus, thallus terlihat lembek, dan air laut dalam botol penanaman menjadi keruh (gambar 1). (Raihana, 2011).

Hasil uji katalase menunjukkan bahwa semua isolate bakteri yang diperoleh dari hasil isolasi memiliki enzim katalase. Hal ini diketahui dari gelembung-gelembung gas yang terbentuk pada saat pengujian. Gelembung-gelembung gas tersebut berasal dari hydrogen peroksida $(\mathrm{H} 2 \mathrm{O} 2)$ yang terurai menjadi air dan oksigen oleh aktivitas enzim katalase. Hidrogen peroksida bersifat toksik terhadap sel karena bahan ini menginaktifkan enzim dalam sel. Hidrogen peroksida terbentuk sewaktu metabolisme aerob, sehingga mikroorganisme yang tumbuh dalam lingkungan aerob pasti menguraikan bahan tersebut (Lay, 1994).

Uji glukosa dilakukan untuk mengetahui bakteri yang mampu memfermentasikan glukosa. Pada media glukosa terbentuk gelembung pada tabung durham yang artinya hasil uji glukosa positif ,yaitu bakteri mampu memfermentasi glukosa dengan hasil fermentasi berbentuk gas. Sedangkan hasil negative ditunjukkan dengan tidak terbentuknya gas.

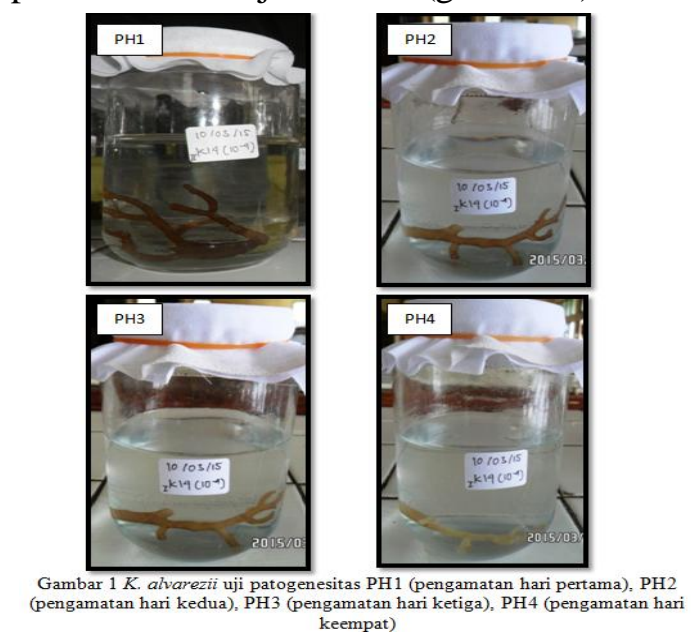

Penyakit ice-ice ditandai dengan timbulnya bintik/bercak-bercak merah pada sebagian thallus yang lama kelamaan menjadi kuning pucat dan akhirnya berangsur-angsur menjadi putih. Penyakit ini menginfeksi pangkal, batang dan ujung thallus muda (Arisandi et al., 2013), thallus menjadi rapuh dan mudah putus. Gejala 
yang diperlihatkan adalah pertumbuhan yang lambat, terjadinya perubahan warna menjadi pucat dan pada beberapa cabang menjadi putih dan membusuk (Arisandi et al., 2011).

Stress yang diakibatkan perubahan kondisi lingkungan yang mendadak yaitu perubahan salinitas, suhu air dan intensitas cahaya, merupakan faktor utama yang memacu timbulnya penyakit ice-ice. Ketika rumput laut mengalami stress akan memudahkan infeksi patogen. Pada keadaan stress, rumput laut (misalnya: Gracilaria, Eucheuma atau Kappaphycus) akan membebaskan substansi organik yang menyebabkan thallus berlendir dan merangsang bakteri tumbuh melimpah. Kejadian penyakit ice-ice bersifat musiman dan menular (Arisandi \& Farid, 2014).

Largo et al., (1999) menjelaskan mekanisme infeksi bakteri pada K. alvarezii sehingga dapat menimbulkan gejala ice-ice. Bakteri menempel pada makro alga yang stress, selanjutnya berkembang biak pada dinding sel dengan memanfaatkan polisakarida (karagenan) sebagai medianya atau sumber karbonnya. Setelah dua sampai tiga hari kemudian bakteri masuk ke dalam jaringan sampai pada lapisan medulla dengan cara menghidrolisa enzim karaginase (Lin dalam Yulianto \& Mira, 2009), akibatnya warna thallus menjadi pucat/putih, jaringan lembek serta thallus mudah terputus. Selain itu, Musa \& Wei (2008) dalam Arisandi et al., (2011) menyatakan bahwa infeksi bakteri dapat berpengaruh terhadap jaringan dan sel makro alga, sebab menurut Hamoda (1995) dalam Arisandi et al., (2011) beberapa bakteri memiliki kemampuan menghasilkan enzim ekstraseluler yang dapat diekskresikan ke luar selnya, sehingga mampu mendegradasi senyawa organik yang terdapat pada lingkungan tempat tumbuhnya, seperti dinding sel thallus makro alga. Lakitan (2011) menyatakan bahwa, dinding sel tanaman mempunyai fungsi utama sebagai pelindung dan rangka sel, sehingga apabila dinding sel mengalami kerusakan atau terdegradasi maka dapat mengakibatkan terjadinya perubahan bentuk sel.

Karakterisasi ulang yang telah dilakukan terhadap bakteri yang positif menyebabkan gejala ice-ice menunjukkan bahwa, isolat bakteri tersebut memiliki karakter yang sama dengan isolat K-25 yaitu bentuk koloni bulat, ukuran sedang, permukaan halus, tepian rata, Gram positif bentuk bacil, koloni berwarna kuning pada media TCBS dan berwarna pink pada media MCA, uji katalase positif, uji glukosa positif. Dengan demikian, dapat dinyatakan bahwa isolat K25 adalah bakteri patogen penyebab penyakit ice-ice pada $K$. alvarezii yang dibudidayakan di Teluk Bumbang pulau Lombok.

\section{KESIMPULAN}

Adapun kesimpulan yang dapat diambil dari penelitian ini adalah terdapat 28 isolat bakteri yang berasosiasi dengan Kappaphycus alvarezii yang bergejala ice-ice. Hasil uji patogenesitas ke-28 isolat tersebut diperoleh satu isolat bakteri yang mampu menyebabkan gejala ice-ice yaitu isolat $\mathrm{K} 25$.

\section{DAFTAR PUSTAKA}

Aris, Muh.. 2011. Identifikasi, patogenisitas bakteri dan pemanfaatan gen 16s-rrna untuk deteksi penyakit ice-ice Pada budidaya rumput laut (Kappaphycus alvarezii). Tesis. IPB.

Aris, M., Sukenda, Enang, H., M.F. Sukadi, M. Yuhana. 2013. Identifikasi Molekuler Baketri Patogen dan Desain Primer PCR. Budidaya Perairan September 2013 vol.1 No. 3:43-50.

Arisandi, A., dan Farid, A. 2014. Dampak Faktor Ekologis Terhadap Sebaran Penyakit Ice-ice. Program Studi Ilmu Kelautan Fakultas Pertanian Universitas Trunojoyo. Jurnal Kelautan Volume 7, N0. 1, April 2014 ISSN: 1907-9931.

Darmayati, yeti. 2010. Bakteri Phatogenik penyebab Penyakit pada rumput laut kappaphycus alvarezii (Doty, 1986), (Eucheuma

cottonii)http://www.sidik.litbang.kkp.g o.id/index.php/searchkatalog/byId/130 9 [Diakses 13 agustus 2014 (08:44)].

Darmayati, Y.A., Hatmanti, N., Farida dan Surahman. 2001. Studi Hama Penyakit. Laporan Akhir Penelitian Pengembangan bibit unggul Rumput Laut, Pengelolaan Kualitas Air Serta Hama dan Penyakitnya. Proyek Penelitian, Pengembangan dan Pemanfaatan Sumberdaya Laut Dalam. Pusat Penelitian Oseanografi -LIPI Jakarta. 
Hamsah dan Patadjai, R. S.. Identifikasi Vibrio sp. Yang Diisolasi Dari Rumput Laut Kappaphycus alvarezii Yang Terserang Penyakit Ice-Ice. AGRIPLUS, Volume 23 Nomor : 01 Januari 2013, ISSN 0854-0128.

Jaelani, Irwan. 2014. Bakteri Asosiasi Pada Karang Pachyseris sp. yang Terinfeksi Penyakit BBD (Black Band Disease) di Perairan Pulau Barrang Lompo. Skripsi. Universitas Hasanuddin. Makassar.

Jailani, A.Q., Abida, I.W., dan Triajie, H.. 2011. Laju Kecepatan Penyerangan Ice-ice Pada Rumput Laut Eucheuma cottonii di Perairan Bluto Sumenep Madura. Fakultas Pertanian Universitas Trunojoyo.

Lakitan, B.. 2011. Dasar-dasar Fisiologi Tumbuhan. Edisi ke-1, Cetakan ke-9. Jakarta. PT Raja Grafindo Persada.

Raihana, Nadia. 2011. Profil Kultur dan Uji Sensitivitas Bakteri Aerob dari Infeksi Luka Operasi Laparatomi di Bangsal Bedah RSUP dr. M. Djamil Padang. Padang. Universitas Andalas. Artikel.

Sidharta, B. R. 2000. Pengantar mikrobiologi kelautan. Yogyakarta. Universitas Atmajaya.

Waluyo, L..2010. Teknik Metode Dasar Mikrobiologi. UMM Press. Malang.

Widiastuti, I.Gst.A.A..2009. Petani Rumput Laut: Bertahan di Tengah Perubahan Iklim. Article PDF.

Yulianto, K., dan Mira S.. 2009. Budidaya Makro Alga Kappaphycus alvarezii (Doty) secara Vertikal dan Gejala Penyakit "ice-ice" di Perairan Pulau Pari. Oseanologi dan Limnologi di Indonesia (2009) 35(3): 323-332 ISSN 0125-9830. 